\title{
Changing trends in dietary pattern and implications to food and nutrition security in Association of Southeast Asian Nations (ASEAN)
}

\author{
Jan Mei Soon ${ }^{1, *}$, E. Siong Tee ${ }^{2}$ \\ ${ }^{1}$ Faculty of Agro-Based Industry, Universiti Malaysia Kelantan, Jeli, Kelantan, Malaysia \\ ${ }^{2}$ Nutrition Society of Malaysia, Kuala Lumpur, Malaysia \\ Email address: \\ janmei.soon@yahoo.com (J. M. Soon),president@nutriweb.org.my (E. S. Tee)
}

\section{To cite this article:}

Jan Mei Soon, E. Siong Tee. Changing Trends in Dietary Pattern and Implications to Food and Nutrition Security in Association of Southeast Asian Nations (ASEAN). International Journal of Nutrition and Food Sciences. Vol. 3, No. 4, 2014, pp. 259-269.

doi: $10.11648 /$ j.ijnfs.20140304.15

\begin{abstract}
Availability, accessibility and food affordability does not necessarily guarantee its nutritional quality. A core component of food security includes nutrient utilization which reflects the need for dietary quality for an active and healthy lifestyle. Traditional diets particularly in urban areas are being replaced by diets higher in fats, salts and animal products and often with lower intakes of fresh fruits and vegetables resulting in a nutrition transition. Food consumption expressed in kilocalories (kcal) per capita per day is a key variable for measuring and evaluating the changes in dietary patterns. Back in the 1970s, the food consumption per capita in Indonesia, Lao PDR, Myanmar, Philippines and Vietnam measured less than $2200 \mathrm{kcal} / \mathrm{day}$. A daily energy intake of $2200 \mathrm{kcal}$ is regarded as necessary to avoid malnutrition. At present, it would appear that all SEA countries have increased to more than $2300 \mathrm{kcal} / \mathrm{day}$. Obesity can co-exist with malnutrition in the same society. When food insecurity exists, dietary quality may be compromised which leads to higher intake of energy from food that are high in fat and carbohydrate, but low in nutrients and lack diversity. There have been increases in energy contribution from added vegetable oils and added sugars. Drivers for dietary pattern changes include trade liberalisation, international food trade leading to 'burgerization', foreign direct investment, emergence of supermarkets and fast food chains, increase in income and socioeconomic gains, urbanisation and access to social and mass media. Nutrition-related non-communicable diseases (NR-NCD) stems largely from the transition from traditional to contemporary patterns of food consumption and physical activity. Intervention strategies include rolling out the National Plan of Action for Nutrition (NPAN) (e.g. in Malaysia) which aims to ensure household food and nutrition security for all and to prevent and control diet-related non-communicable diseases. Economic measures such as imposing tax on sugar and energy-dense but nutrient-poor food. Labelling, home economics emphasizing the importance of nutrition security and the promotion of traditional healthy diets should be targeted among local communities and in the education system.
\end{abstract}

Keywords: ‘Burgerization', Drivers for Change, Nutrition Transition, Traditional Diets

\section{Introduction}

Feeding the 9 billion people expected in 2050 will be a global challenge. The World Food Summit defined food security as existing "when all people at all times have access to sufficient, safe, nutritious food to maintain a healthy and active life". Food security is conceptualized as resting on three pillars: availability, access and utilization. Adequate availability is necessary and is made possible by advances in agricultural production. Access is most commonly related to having sufficient resources to obtain appropriate foods.
However, both availability and accessibility does not necessarily guarantee its nutritional quality [1]. Hence, in this case, utilization reflects concerns of how individuals and households make good use of the food to which they have access. Barrett [2] raised the interesting question of whether they consumer nutritionally essential foods they can afford, or do they choose nutritionally inferior diet? Utilization in food security emphasizes the need for dietary quality, particularly micronutrient deficiencies associated with 
inadequate intake of essential vitamins and minerals. In contrast, another arising challenge faced by developing countries, is overnutrition as a result of excess calorie intake. Hence the term nutrition security is used to represent the quality dimension [3]. Nutrition is a fundamental human need. The absence of food and nutrition security can have significant effects such as malnutrition, obesity, disease and poverty [4]. Thus this paper strives to review the changing dietary patterns occurring in South East Asia countries, using Malaysia as a key example. In addition to the three pillars of food security, it is apt that the Department for Environment, Food and Rural Affairs (Defra) included affordability within their national food security policy. Affordability is very much ingrained in shaping a household, a community, a region and a nation's nutritional status. Affordability is about food being available at prices that people can afford to pay, particularly among low-income consumers to encourage them to buy enough nutritious food to meet their basic health needs [5].

\section{Nutrition Transition}

\subsection{Changes in Dietary Pattern in South East Asia Countries}

We are intimately connected to local agriculture and food and it is interesting to note how our dietary patterns have evolved and changed through the years. For example, Thailand has a strong food culture and has access to an abundant of local sources of healthy fresh foods. Traditional Thai diets can be considered to be protective against chronic diseases due to the rich diet of fresh fruit and vegetables, herbs, legumes and cereals with the majority of protein sourced from fish [6]. Similarly diets in other South East Asia countries are based on rice accompanies by vegetables and a fish or meat stir-fry or soup. Varieties of fresh, cooked or pickled vegetables are often used [7, 8]. Traditional diets particularly in urban areas are being replaced by diets higher in fats, salts, sugars and animal products and often with lower intakes of fresh fruits and vegetables resulting in a nutrition transition [6]. Hence it is important to study how local food cultures and diets react to these upstream influences within the global food supply chain.

The stages in nutrition transition and changes in dietary patterns can be observed in Fig. 1. Since the hunter-gather age, human population has evolved to farming (Stage 2) followed by industrialization (Stage 3). In Stage 3, famine begins to decrease as income rises. Developed countries have been in Stage 4 for some time, where life expectancy is high, but affected with nutrition-related non-communicable diseases and obesity [9]. Developing countries, and South East Asia in this context are within or moving towards Stage 4.

Food consumption expressed in kilocalories (kcal) per capita per day is a key variable for measuring and evaluation the changes in dietary patterns. Fig. 2 shows that the consumption of kcal from 1970s to 2000s increased in all South East Asia countries (except Singapore, data not shown)
[11]. Back in the 1970s, the food consumption per capita in Indonesia, Lao PDR, Myanmar, Philippines and Vietnam measured less than $2200 \mathrm{kcal} /$ day. A daily energy intake of $2200 \mathrm{kcal}$ is regarded as necessary to avoid malnutrition. At present, it would appear that all SEA countries have increased to more than $2300 \mathrm{kcal} /$ day. Although the average food consumption of all countries indicates adequate kcal intake, it is noted that Brunei, Malaysia and Thailand, followed closely by Viet Nam and Indonesia are consuming more than 2700 - 2900 kcal per day. Most South East Asia countries projected a slow increase in sugar consumption, with the exception of Thailand [11]. Sugar consumption was estimated at $9.9 \mathrm{~kg} /$ year in 1970 and increased to 28.9 $\mathrm{kg} /$ year in 2009 . This will lead to obesity in people with a sedentary lifestyle [12]. It is also projected that food consumption will reach $2980 \mathrm{kcal} /$ day in developing countries, whilst transition countries will hit $3180 \mathrm{kcal} /$ day by year 2030 [13].

Obesity can co-exist with malnutrition in the same society. According to Hammond and Dube [4], obesity may be linked to the same factors that cause malnutrition. Poverty leads to hunger and food insecurity but may also result in overnutrition, and subsequently obesity [14]. When food insecurity exists, dietary quality may be compromised which leads to higher intake of energy from food that are high in fat and carbohydrate, but low in nutrients and lack diversity. Energy-dense foods are often less expensive than foods based on lean meats, fish, fruits, vegetables and whole-grains [15]. Global meat consumption increased from 47 million tonnes in 1950 to 260 million tonnes in 205. The consumption per person doubles from 17 to $40 \mathrm{~kg} /$ year [16].

\subsection{Scenario of Changes in Agricultural Production and Food Import in Association of Southeast Asian Nations (ASEAN)}

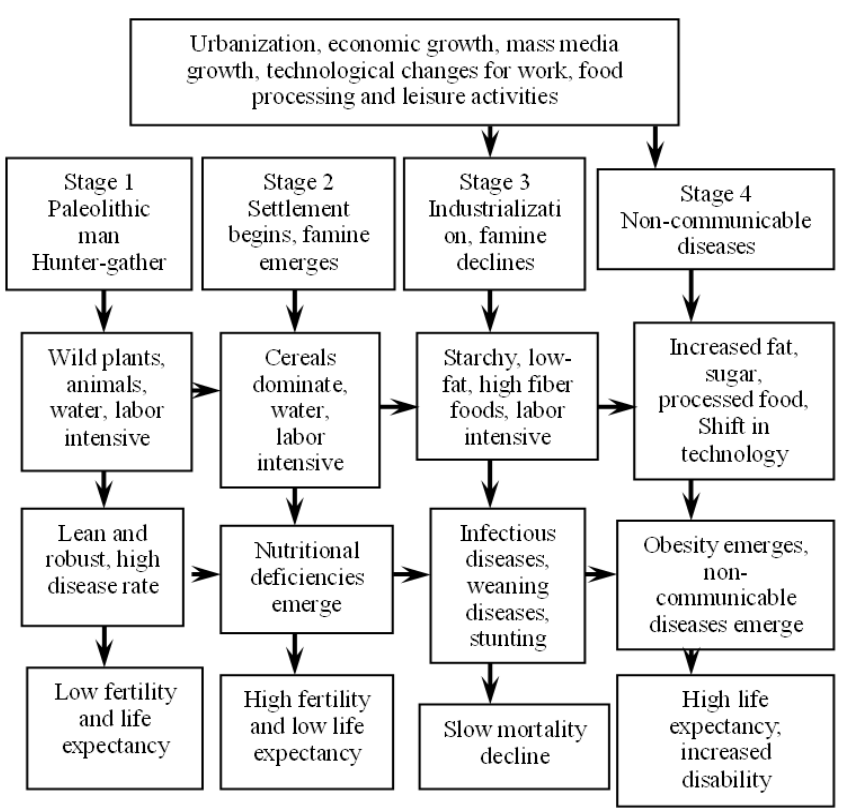

Figure 1. Stages in nutrition transition (Adapted from 9, 10) 
Based on Fig. 3, there is more than 200\% increase in rice production and import between 1970 and 2009 for all ASEAN countries. The domestic utilization of rice rose to more than $100 \%$ between the 4 decades. Rice production needs to be increased to support the increasing population. For example, in 1970 the total population in Indonesia numbered at 118 million whilst in 2009 the population has risen to 237 million [11].

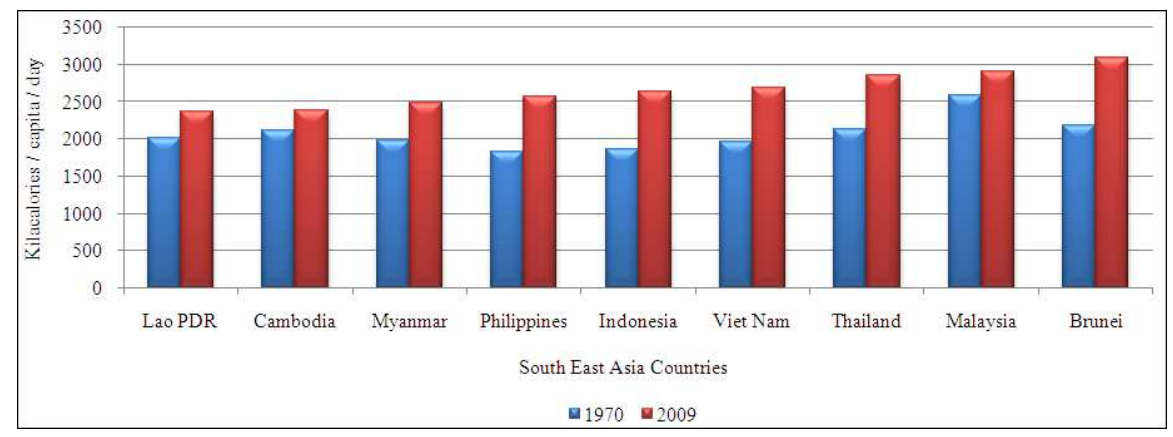

Figure 2. 1970 vs. 2009: Energy availability in South East Asian countries (kcal per capita per day) [11]

Rice is the staple food of ASEAN nations. As ASEAN's population continues to grow, there is need for scaling up and increasing productivity of agro-food production such as rice farming. In Malaysia the Government continues to develop the agro-food sector to ensure food security. Strategies to increase production and to meet the self-sufficiency level (SSL) have been applied. Among others, existing rice granaries will be strengthened through an integrated and systematic rice management system. Additionally four new granaries will be developed in Malaysia, creating new total area of 19,000 hectares with expected production of 104 tonnes and generating income for more than 12,000 farmers. This will supplement the current production of 1.8 million tonnes from existing granary areas of 389,000 hectares $[17,18]$.

\subsubsection{Scenario of Changing Diets / Trends in ASEAN, with Specific Focus on Malaysia}

Food balance sheet data from the 1970 s through to the late 2000s show significant changes in food sources of dietary energy in the Malaysia. There have been increases in energy contribution from added vegetable oils.

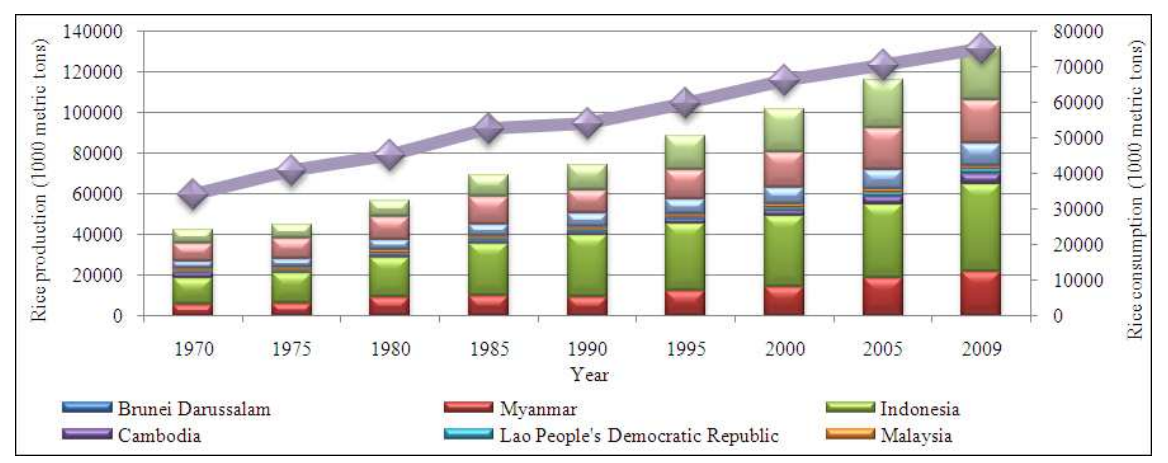

Figure 3. Rice production and consumption in South East Asia countries between 1970 and 2009

Kilocalorie contribution from rice decreases from 1176 $\mathrm{kcal} /$ day to $731 \mathrm{kcal} /$ day. Based on Figure 4, it seems that Malaysians are moving away from their staple diet towards wheat-meat-oil-fat-sugar-based diets. On the other hand, the consumption of sugar and sweeteners did not vary much. For example, the consumption of sugar and sweeteners numbered at $37.2 \mathrm{~kg} /$ year/capita in 1970 and 40.2 $\mathrm{kg} /$ year/capita in 2009.

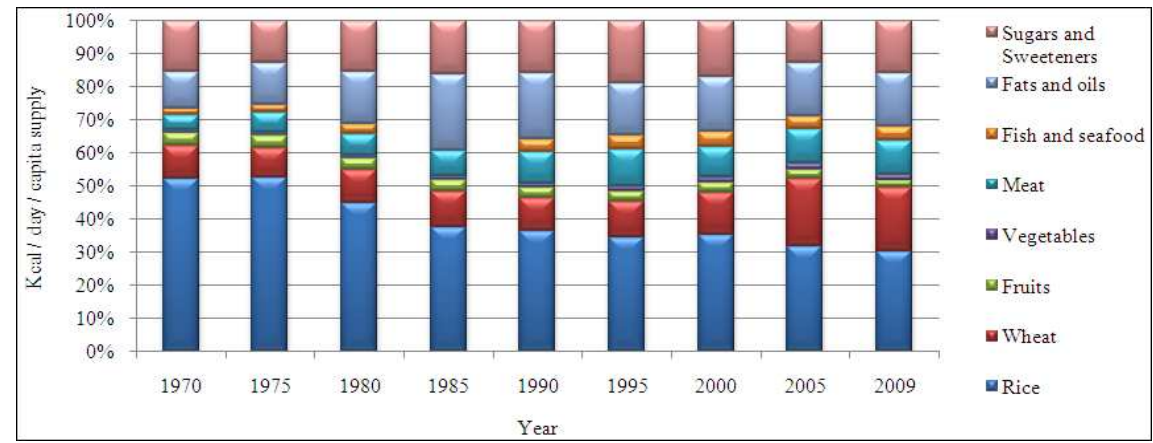

Figure 4. Kilocalorie contribution of various food commodities in Malaysia between 1970-2009. 
Changes in dietary pattern are characterized by a decline in the consumption of traditional staple food (i.e. rice) and other traditional food crops such as sweet potatoes, cassava, pulses and oilseeds. There is an increase of preference for wheat and animal protein. There is a slight increase in vegetable intake but not much variation in fruits consumption.

The increased intakes of meat, wheat-based products, fats and oil and sweeteners largely contribute to the percentage of total energy. The overall reduction in dietary diversity and an increase in consumption of refined and processed foods have an impact on health. Such changes in the dietary pattern can lead to an increase in diet-related diseases such as late onset diabetes, cancers and cardiovascular disease [19].

Westernization of diet and moving away from traditional staple food has occurred. Based on Figures 2 and 4, the increase in total kcal consumption is due to higher fat and protein content and reduced calorie intake from cereal-based product.

\section{Drivers for Changing Dietary Pattern}

What is driving the increasing prevalence of energy-dense and nutrient-poor diets? The corresponding changes that have taken place in the economic, environmental and cultural circumstances have changed the nature of people's living and working conditions.

\subsection{International Food Trade}

According to Blouin et al. [20], trade liberalisation has facilitated the availability of highly processed, calorie-rich, nutrient-poor food by removal of barriers to foreign investment in food distribution. Significant trade changes occur after the 1994 Uruguay Round of the General Agreement on Tariffs and Trade (GATT) which opened up a number of countries to international market. The GATT Agreement on Agriculture pledged countries to reduce tariffs, export subsidies and domestic agricultural support. The trade liberalisation has enabled foreign direct investments and penetration and enlargement of multinational food companies into developing countries [21]. Trade liberalisation has also enable foreign investment in other types of food retail such as the setting up of fast-food chain in Vietnam.

\subsection{Burgerization}

Today, fast food is a part of all cultures. The global spread of the three big US fast food corporations - McDonald's, Burger King and Yum! Brands (Kentucky Fried Chicken, Pizza Hut and Taco Bell) has come to represent fast food and influenced our eating habits. Fast food are defined as restaurants that provide quick food service (similar to production line techniques), western pattern diets, established standard operating procedures and have franchises in multiple states or nationwide [22]. Fast food and ready meals tend to be high in animal fats. Their popularity has been said to contribute to the rising levels of obesity in the industrialized world, particularly in the USA [23].

McDonald's will also be opening its first restaurant in Vietnam in early 2014. This move also follows a series of fast-food chains that have recently set up shop in Vietnam, from KFC - which has 130 outlets around the country to Burger King, Subway, Pizza Hut and Starbucks as well as Philippines' favourite chain Jollybee [24].

In Malaysia, the top 3 most popular food brands in Malaysia are McDonald's, Starbucks and Kentucky Fried Chicken (KFC). KFC is one of Malaysia's oldest fast food franchise and started its first operation in 1973. Having stood the test of time, KFC has continued to grow to more than 500 outlets throughout Malaysia. There are more than 140 KFC outlets in other ASEAN countries including Singapore, Brunei and Cambodia. Malaysia fast food industry began in 1963, when A \& W opened its first outlet [25]. Global fast food franchises also tend to advertise and promote their brands to ensure a greater media and social network coverage. Today, the fast food services extend to breakfast, lunch, dinner, 24-hour service and drive through [26]. Fast food restaurants are particularly well liked by youngsters who in turned influence their parents decision of which restaurants to visit [25].

\subsection{Local “Fast Food' Consumption in Malaysia}

Local "fast foods" are also major contributing factors. Local fast food are on sale literally everywhere and throughout the day in Malaysia ranging from roadside hawker stalls to posh restaurants. The nasi lemak(rice cooked in coconut milk), char koay teow (fried noodles), curry mee, satay (meat skewered on sticks and grilled over charcoal fire) and fried banana fritters are a few examples of local food that have excessive fat, high animal meat, coconut milk and are low in fibre. Many local dessertsare also high in sugar and coconut milk. These local "fast food" are widely consumed, in huge servings, many times a week. Many office workers have limited access to healthier choices at or around their work place. Many families that eat out do not make serious efforts to make such choices.

\subsection{Foreign Direct Investment}

Foreign Direct Investment (FDI) can be defined as a long term investment by an enterprise in one country into an enterprise of another. The foreign enterprise becomes a foreign affiliate of a parent company, thus creating a transnational corporation (TNC) [21, 27]. FDI is one of the mechanisms through which TNCs enter new markets. The flow of FDI in the food retail sector was led by global retail multinationals. For example, in 2002, five global retailers (British Tesco, French Carrefour and Casino, Dutch Ahold and Makro, and Belgian Food Lion) invested 6 billion bhat 
(US\$120 million) in Thailand [28]. Increasing levels of FDI by multinational food companies in developing countries played a role in nutrition transition by shaping the processed foods market and making more processed foods available in developing countries. For example, Tesco Malaysia is a 30:70 joint venture between local conglomerate Sime Darby Berhad and United Kingdom's Tesco Ltd.

TNCs invested in overseas to gain from the potentially high returns due to the growing population in developing countries. This will result in a far higher growth potential than the more matured markets of developed nations. FDI in food processing is the better at generating overseas sales than exports of processed food. This is because exporting processed foods can incur high transport and storage costs relative to the value of the product [29]. Instead these processed foods can be produced in the invested country, particularly when the host country has the raw materials available for production, thus reducing the delivery costs of exports. FDI does a play a role in shaping the local markets with highly processed foods in developing countries. As a consequent, FDI drives sales and consumption of highly processed foods [30].

\subsection{Emergence of Supermarkets and Fast Food Chains}

From the earliest to the latest adopter of supermarkets, the first wave of supermarkets hit Latin America, followed by Asia and then Africa. In a single decade, the growth of supermarkets in Latin America equals to the development of supermarkets that the United States experience in five decades. Likewise, the arrival and development of supermarkets in South East Asia occurred after the 'take off' of supermarkets in Latin America and registered even faster growth compared to Latin America [31]. Supermarket expansion influence food choices, weight and health. Banwell et al. [32] examined the food retail environment in Thailand and compared traditional fresh markets in four Thai regions with newer supermarkets. Supermarkets are positive by allowing a more diverse diet available and accessible to more people [32]. It can be negative, since supermarkets can reduce the ability of marginalized populations to purchase a high-quality diet and encourage the consumption of energy-dense and highly processed foods [33, 34]. Energy-dense foods are relatively cheap sources of energy but with low nutrient density. People with a low income may therefore select a less healthy diet and the high energy density may explain the association between obesity and low socioeconomic status. Examples of energy dense food are cookies, candies, peanut butter, jam and chocolate [35].

In Thailand, hypermarkets sell processed products $12 \%$ cheaper and fresh foods $10 \%$ dearer than do traditional retailers [36]. This is in agreement with Isaacs [37] where fresh produce at supermarkets were two to four times more expensive than fresh markets. Whereas in Indonesia, traditional retailers in Jakarta sell mixed grades (ABC) tomatoes at $3100-3400$ rupiah per $\mathrm{kg}$ versus supermarkets, grade A and super A at 4900 - 5200 rupiah per $\mathrm{kg}$ [38].In Vietnam, fresh produce (e.g. staple kangkong, water spinach) is $30-50 \%$ more expensive while tomatoes are modestly more expensive (10-20\%) [39].

Supermarkets charged lower prices for processed products compared to traditional retailers. This is possible due to the bulk procurement systems and economies of scale. Hence, poor consumers will have access to processed foods and semi processed foods. Supermarkets tend to sell vegetables and fruits more expensively than do traditional retailers [36]. Smallholder farmers or local market owners are often at a disadvantage compared with larger commercial farmers and supermarkets capable of supplying larger volumes of quality-assured products with more bargaining power and better access to information, technical services and capital [40]. Supermarkets are well placed to sell processed foods at lower cost due to economies of scale in procurement. The growing use of refrigerators and cars in many developing countries facilitates weekly shopping for processed foods [41].

\subsection{Increase in Income and Socioeconomic Gains}

A high economic growth increased food availability and enhanced purchasing power of people. This accelerates changes in dietary pattern. The more people earn, the higher their consumption of nutrient rich animal-source food. As people emerge from poverty, dietary diversification which includes increased consumption of milk, meat and eggs tend to be one of the first manifestations of poverty reduction [3]. The per capita gross national income was less than 9,000 international \$ (Int\$) in year 2000, and then increased to $16,530 \mathrm{Int} \$$ in 2010. An international dollar is a hypothetical unit of currency that has the same purchasing power as a U.S dollar in the United States and is used to make comparisons both between countries and over time [42]. An increase in income and subsequent investments in technological innovations also affected energy expenditures in leisure, transportation and work [23].

Industrial development and commercialisation of agriculture has also resulted in growth of GDP. The shift in income is also associated with changes in occupation distribution. The shift from labour intensive work in agricultural sector to manufacturing and services has reduced the amount of energy expenditure among Malaysians. In $1980 \mathrm{~s}$, there were 1.6 million workers working in the agriculture, forestry and fishing sector followed by more than 800 thousand workers in manufacturing and 2.3 million workers in the service sector. Fast forward to 30 years, the number of employment remains at 1.6 million, whilst manufacturing and services increased to 2.2 and 7.3 million! [43].

As more women enter the workforce, this reduces the available time to prepare food at home. During the $80 \mathrm{~s}$, there were 1.6 million women in the workforce compared to 4.2 million in 2010 (an increment of 62\%). In comparison, there are 7.5 million males employed in Malaysia whilst in 1980, there were 3.1 million, marking an increase of 57\% [43]. 
Although men numbered more in total, nevertheless, there is a stark increase in women joining and contributing to the household income.

\subsection{Urbanization and Access to Social and Mass Media}

In addition to population growth, urbanization, a growing middle class and rising incomes, the rapid expansion of supermarkets and wholesalers in developing countries have been well documented in the literature [28]. Urbanization creates a new and improved marketing and distribution infrastructure (i.e. cold chains), attracts supermarkets, and improves roads and ports. The penetration and influence of modern communications, removal of communication barriers are also related to globalization [44]. For example, fast food restaurants and their ready-to-eat takeaway products have been heavily advertised as a tasty, nutritious and relatively cheap means of feeding the family.

\section{Nutrition and Health Concerns}

Nutrition-related non-communicable diseases (NR-NCD) stems largely from the transition from traditional to contemporary patterns of food consumption and physical activity [45] (Nazmi and Monteiro, 2013).Limited availability of open spaces and parks, increased rural to urban migration and illegal settlements also reduce the scope for physical activity. The trend towards more 'westernized' work schedules and increased participation of women in the labor force are increasing the demand for food purchasing options offered by modern supermarkets [38]. Additionally, in most urban families, working parents have less free time to plan proper nutrition and cook healthy meals for their children [46]. Out of home food consumption also reduces a person's control over both the total calories consumed and the nutritional quality of foods consumed, especially in relation to the types of fats and sugars compared with foods prepared and consumed at home [47].

In Malaysia, there has been marked decrease in nutrient deficiencies over the last 40 years $(1970$ s - 2010). However, undernutrition, although sparingly, still exists among rural and urban underprivileged groups. On the other hand, overnutrition occurs, resulting in increases of diet-related chronic diseases such as obesity, hypertension, coronary heart disease, diabetes and cancers [48].

Obesity has become a major problem among Malaysians and is the main cause for diet-related non-communicable diseases. This is especially alarming as $16 \%$ of our pre-school children and $30 \%$ of our primary school children are overweight. These overweight children are more likely to continue to become overweight and obese adolescents and eventually overweight and obese adults [49].There are significant increases in NCD between 2006 and 2011 with the exception of a marginal increase for overweight and obesity (Table 1).

Why is there an increase in non-communicable chronic diseases? In Malaysia, dramatic lifestyles of the community have occurred. These include rapid advancements in socio-economic situation in the country which resulted in significant changes in lifestyles. More families are eating out, increased consumption of "fast food" and fried foods, tendency to overeat, availability of huge portion sizes and inappropriate use of nutrient supplements. Inappropriate dietary patterns and sedentary lifestyles are the two main causative factors in obesity and chronic diseases. These diseases are preventable and public must adopt healthy eating and active lifestyle practices to prevent obesity, hypertension, heart disease, diabetes and even cancers.

\subsection{Implications to Food and Nutritional Security}

Meat and fish consumption contributes directly to nutritional security since meat and fish are sources of protein, essential fatty acids, micronutrients such as Vitamin A, calcium, zinc and iron [50]. Seafood is also a preferred and culturally important food choice in ASEAN region [51] (Dey et al. 2008). Production and consumption of meat and fish have serious consequences for global food security and the environment [52, 53, 54]. As meat consumption increases, the increased demand for grain by feedlots may limit the supply available for poorer communities.

Table 1. Increase in non-communicable diseases (\%) in adults (> 18 years)

\begin{tabular}{lll}
\hline Non-communicable diseases & $\mathbf{2 0 0 6}$ & $\mathbf{2 0 1 1}$ \\
\hline Overweight and obesity & 43.1 & 44.5 \\
High blood cholesterol & 20.7 & 32.6 \\
Hypertension & 32.2 & 32.7 \\
Diabetes mellitus & 11.6 & 15.2 \\
\hline
\end{tabular}

Increased demand for beef can only be met from two main sources: (i) rapidly expanding feedlot production; and (ii) intensification and spatial expansion of managed grazing systems. Both have significant regional and global environmental impacts [53].

Changes in consumption pattern are also responsible for changing the requirements for available agricultural area. A shift from a vegetarian diet to an affluent diet with meat leads to an increase in land required. For example, the International Food Policy Research Institute (IFPRI) calculated that annual per capita meat consumption increases, on average from $90 \mathrm{~kg}$ per person per year to over $100 \mathrm{~kg}$ between 2000 and 2050 in high-income countries, and from around $25 \mathrm{~kg}$ to $45 \mathrm{~kg}$ per person per year in low-income countries during the same period. On average, the production of beef protein requires several times more amount of land than vegetable proteins such as cereals [55].

Supermarkets too are implicated in increasing the level of pressure on the environment. It is the supermarkets that purchase foods from distant locations, thus adding to the 'food miles' associated with certain foodstuffs and depleting energy resources in the process [56].

Dietary changes, less physical activity, sedentary recreation and occupational changes affects body sizes resulting in increase in \% of overweight and obesity [32]. Nutrition related non-communicable diseases (NR-NCD) 
such as cardiovascular diseases, diabetes and cancer are expected to surge. This will result in considerable economic and social costs. Popkin [44] predicted that the costs of obesity and related diseases in China and India will outstrip the costs of nutrition in the next 15 years.

\section{Intervention Strategies}

\subsection{Malaysia's Nutritional Policies and National Plan of Action for Nutrition}

The main policy and national plans to address nutrient deficiencies and diet-related non-communicable diseases are the National Nutrition Policy (2005) and the National Plan of Action for Nutrition (NPAN) of Malaysia. The first NPAN Malaysia (1996 - 2000) was developed in 1995 , after the FAO/WHO International Conference of Nutrition in 1992. After a thorough review of the nutrition situation in the country, the national plan was updated as the second NPAN (2006 - 2015), where a mid-term review was conducted in July 2010.

Both the National Nutrition Policy and NPAN II aim to ensure household food and nutrition security for all and to prevent and control diet-related non-communicable diseases. In order to ensure the effective implementation, monitoring and evaluation of the Plan of Action, strategies of the Plan are oriented into (i) Foundation; (ii) Facilitating; and (iii) Enabling Strategies.

The Foundation strategy forms the overarching strategy for the implementation of the Plan, followed by five Facilitating strategies which provide the mechanism and support for the realisation of the Enabling strategies. The five Enabling strategies focus on direct impact on achieving the specific objectives of the NPAN II (Figure 5).

\subsection{Promoting Healthier Food Choices}

Communities should be provided with equally delicious but healthier local food choices. For example, instead of opting for deep fried food, one can select alternatives like grilled, steamed and blanched or boiled. Stir-fried, steamed or soup-based vegetables should accompany the meals to ensure adequate intake of fibre. This can be coupled with local fruit consumption or juice to boost the intake of multivitamins, phytochemicals and intake of $\geq 5$ servings of fruits and/or vegetables per day. Local fruits such as rambutan, mangoes, carambola, langsat and mangosteen are abundant in nutrients and extremely tasty. It might be easier said than done when locals are advised to cut back on salt, fat and sugar. Salt consumption can be reduced by avoiding highly processed meat such as sausages and luncheon meat which contains a high amount of sodium content. One can avoid from having too much gravy and when eating noodle soup, one should avoid drinking the soup. These are small steps that can be taken by consumers in reducing the total salt and fat intake.

How can one reduce sugar consumption? After all sugar is natural and represents food pleasure. Lustig et al. [57] argued that increased sugar consumption is responsible for obesity and other related diseases and should be regulated similarly to alcohol and cigarettes. The study proposed adding taxes to processed foods that contain any form of added sugars such as high fructose corn syrup (HFCS) and sucrose. This would include sweetened fizzy frinks and other sugar-sweetened beverages and sugared cereal. There is however no general consensus on this view. Others argue that obesity is more related to excessive fat intake. There is also no agreement that imposing heavier tax on products containing sugar is going to be an effective approach.

\subsection{Economic Measures}

To ensure that trade liberalisation in the food sector does not translate into unhealthy diets and increase in obesogenic environment, options such as intervention to control the price of healthy and unhealthy foods can be considered. Price interventions on energy-rich or 'fat' food have been proposed by adding an extra tax on energy-rich food or reducing the food value added tax (VAT) exemptions. However, the economic consequences and operational efficiency of such price control is heavily dependent on the how responsive consumers are to the price changes induced by higher taxes [58]. One should not forget the possible implications of food taxes, controls or food-subsidies [59]. For example, Guo et al. [60] found that higher pork prices in China helped to reduce intake of energy and saturated fatty acids among rich consumers, but may cause a fall in protein consumption by the poor.

Hawkes [30] also looked at fast food chains and retailers for a voluntary solution to encourage investment in healthier products - less salty snack and baked goods and more low-fat products and nutrient rich foods.

Other common proposed strategies are nutrition labelling and regulating food marketing practices [61]. Labelling is probably the most widely utilised potential tool to influence consumers. However, the concern of nutritional labelling may accrue mainly to groups who are already more educated about nutrition [21]. Marketing can be used more effectively in promoting healthier food choices through media promotion, and provision of information at supermarkets and other points-of-purchase [62].Strategies applied by other countries that can be adopted include building the capacity of school teachers for nutrition promotion, promotion of healthful cooking among professional chefs [63]. In Finland, a successful nutritional intervention programme targeted at local communities where local healthcare, educators and the food and catering industry collaborated to lower the sodium content of foods. Local communities were invited to participate in cholesterol-lowering competitions and berry farms were initiated to encourage local fruit consumption [64]. South Korea promoted the consumption of traditional diet - rich in vegetables and low in fat by providing intensive training to newly married women about the preparation of traditional dishes. 


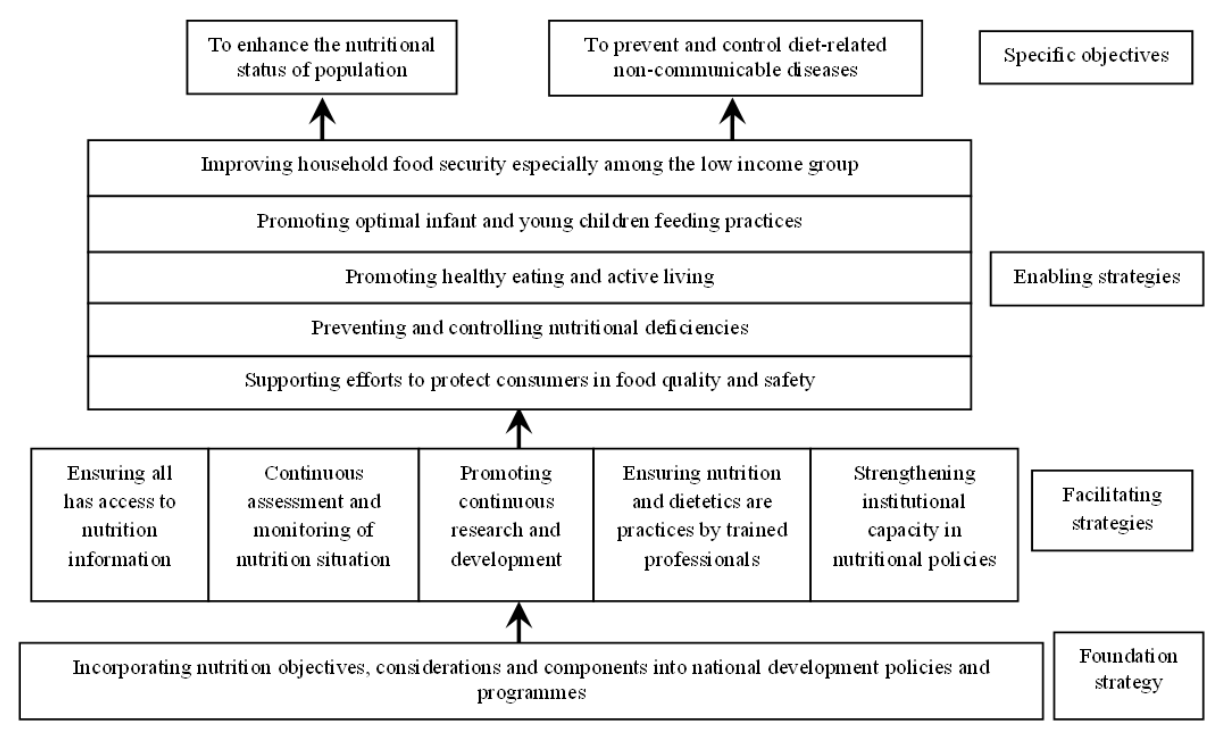

Figure 5. Strategies to achieve and maintain optimal nutrition security and well-being of Malaysians [49].

In this country, mandatory nutrition labelling for a wide variety of foods has been enforced by Ministry of Malaysia since 2005. There was a clear guideline on this regulation and the use of this has been promoted to health staff. The Malaysian Dietary Guidelines 2010 [65] and Dietary

Guidelines for Children and Adolescents [66] have included recommendations to use nutrition labels for making healthier food choices. The Nutrition Society of Malaysia, through the nationwide community nutrition promotion programme, has been advocating the use of nutrition labeling information when making food choices through various publications $[49,67,68,69,70]$ as well as through community out-reach activities. Much more efforts need to be carried out to teach consumers on the use and understanding of nutrition information on food labels.

\section{Conclusion and Recommendations}

Significant changes in dietary pattern have taken place in Southeast Asian countries in the past 3 decades. Per capita energy availability, a key variable for measuring and evaluation of changes in dietary pattern, has risen significantly over the years, in all the SEA countries. However, this increased availability of food, indicating better food security, does not necessarily guarantee its nutritional quality. There have been significant changes in sources of energy in countries over this time period. The consumption of traditional foods (complex carbohydrate foods and root crops) has declined steadily while the intake of meat, fats and oil have increased markedly. In the mean time, the intake of fruits and vegetables have not increased. Other changes in food intake trends include increased intake of western franchised fast foods as well as local "fast foods". Such changes in dietary pattern may be viewed as negative changes in the nutrition security of communities. Food security emphasizes the need for dietary quality, particularly micronutrient deficiencies associated with inadequate intake of essential vitamins and minerals.

These changes in food consumption pattern and lifestyle of communities in SEA have brought about serious nutrition and health concerns in the region. In Malaysia, for instance, obesity and related non-communicable diseases have become the main causes of morbidity and mortality. At the same time, undernutrition and micronutrient deficiencies remain among various underserved communities. Governments have implemented intervention strategies to address both extremes of the nutritional problems. In Malaysia, the National Nutrition Policy and the National Plan of Action for Nutrition have been formulated. These action plans have identified various strategies to promote healthier food choices amongst the community. Although some economic measures such as increased taxes for the so-called unhealthy foods have been proposed, these remain as controversial and would need careful prior to implementation.

Long-term intervention measures must be implemented in countries in the region to tackle the persisting under-nutrition problems as well as the looming obesity and non-communicable diseases. Interventions must focus on infants and young children, inculcating healthy eating habits and active living from young. Other groups that need serious attention are pregnant and lactating women. All stakeholders, including the government, academia, professional groups and consumer groups must work together in combating the prevailing nutritional problems.

\section{Acknowledgements}

The authors gratefully acknowledge the research funding from RAGS (R/RAGS/A07.00/00295A/001/2013/000120) and the Malaysia Ministry of Education for the financial support. 


\section{References}

[1] P. Webb, J. Coates, E. A. Frongillo, B. L. Rogers, A. Swindale, and P. Bilinsky, "Measuring household food insecurity: Why it's so important and yet so difficult to do," Journal of Nutrition, vol. 136, pp. 1404S-1408S, 2006.

[2] C. B. Barrett, "Measuring food insecurity," Science, vol. 327, $825-828,2010$

[3] J. Smith, K. Sones, D. Grace, S. MacMillan, S. Tarawali, and M. Herrero, "Beyond milk, meat, and eggs: Role of livestock in food and nutrition security," Animal Frontiers, vol. 3, pp. 6-13, 2013.

[4] R. A. Hammond, and L. Dubé, "A systems science perspective and transdisiplinary models for food and nutrition security," Proceedings of the National Academy of Sciences, vol. 109, pp. 12356-12363, 2012.

[5] Defra, "Ensuring the UK's food security in a changing world," Department for Environment, Food and Rural Affairs, London, 2008.

[6] M. Kelly, C. Banwell, J. Dixon, S.-A. Seubsman, and A. Sleigh, "Thai Food Culture in Transition: A mixed Methods Study on the Role of Food Retailing," In, C. Banwell, S. Ulijaszek, and J. Dixon (Eds.), When Culture Impacts Health, pp. 319 - 328, Amsterdam: Academic Press, 2012.

[7] P. Stockton, "Nutrition and fasting in Cambodian culture," Ethnomed.

http://ethnomed.org/clinical/nutrition/nutrition-and-fasting-i n-cambodian-culture, 2001.

[8] J. Tu, "Nutrition and fasting in Vietnamese culture. The Vietnamese diet," Ethnomed. http://ethnomed.org/clinical/nutrition/viet-food, 2001.

[9] B. M. Popkin, and P. Gordon-Larsen, "The nutrition transition: worldwide obesity dynamics and their determinants," International Journal of Obesity, vol. 28, pp. S2-S9, 2004.

[10] S. E. Mahady, and J. George, J, "The future liver of the Asia Pacific: Fatter and firmer from more fructose and fortune?' Journal of Clinical and Experimental Hepatology, vol. 3, pp. 106-113, 2013.

[11] FAOSTAT, "Food balance sheets," http://faostat3.fao.org/home/index.html\#DOWNLOAD, 2013.

[12] L. S. Elinder, "Obesity, hunger and agriculture: the damaging role of subsidies," British Medical Journal, vol. 331, pp. 1333-1336, 2005.

[13] A. Vasileska, and G. Rechkoska, "Global and regional food consumption patterns and trends," Procedia - Social and Behavioural Sciences, vol. 44, pp. 363-369, 2012.

[14] S. A. Tanumihardjo, C. Anderson, M. Kaufer-Horwitz, L. Bode, N. J. Emenaker, A. M. Haqq, et al, "Poverty, obesity, and malnutrition: An international perspective recognizing the paradox," Journal of the American Dietetic Association, vol. 107, pp. 1966-1972, 2007.

[15] A. Drewnowski, and S. E. Specter, "Poverty and obesity: The role of energy density and energy costs," American Journal of Clinical Nutrition, vol. 79, pp. 6-16, 2004.
[16] L. R. Brown, "Chapter 9: Feeding seven billion well: Raising water productivity," in, Plan B 2.0: Rescuing a planet under stress and a civilization in trouble. http://www.earth-policy.org/books/pb2/pb2ch9_ss3, 2006.

[17] NST, "2013 Budget highlights. New Strait Times, 28 September,"

http://www.nst.com.my/latest/2013-budget-highlights-font-c olor-red-update-font-1.149645, 2012.

[18] SCM, "The 2013 Budget, Securities Commission Malaysia," http://www.sc.com.my/eng/html/resources/budget2013/budg et2013.pdf, 2012.

[19] E. Millstone, and T. Lang, "The atlas of food," pp. 1 - 128, London: Earthscan, 2008.

[20] C. Blouin, M. Chopra, R. van der Hoeven, "Trade and social determinants of health," Lancet, vol. 373, pp. 502-507, 2009.

[21] C. Hawkes, "Uneven dietary development: linking the policies and processes of globalization with the nutrition transition, obesity and diet-related chronic diseases," Globalization and Health, vol. 2, pp. 4, 2006.

[22] J. P. Block, R. A. Scribner, and K. B. DeSalvo, "Fast food, race/ethnicity, and income: A geographic analysis," American Journal of Preventive Medicine, vol. 27, pp. 211-217, 2004.

[23] B. M. Popkin, "Global nutrition dynamics: the world is shifting rapidly toward a diet linked with noncommunicable diseases," American Journal of Clinical Nutrition, vol. 84, pp. 289-298, 2006.

[24] K. Hodal, "McDonald's opens first branch in Vietnam," The Guardian.

http://www.theguardian.com/world/2013/jul/17/mcdonaldsopens-first-restaurant-vietnam, 2013.

[25] H. Nezakati, Y. L. Kuan and O. Asgari, "Factors influencing customer loyalty towards fast food restaurants," IPEDR, vol. 10, pp. 12-16, 2011.

[26] T. M. Tan, R. Devinaga, and I. Hishamuddin, "The common challenges of brand equity creation among local fast food brands in Malaysia," International Journal of Business and Management, vol. 8, pp. 96-106, 2013.

[27] C. Bolling, and A. Somwaru, "US food companies access foreign markets through direct investment," Food Review, vol. 24 , pp. 23-28, 2001.

[28] T. Reardon, C. P. Timmer, and J. A. Berdegue, "Supermarket expansion in Latin America and Asia," in A. Regmi, and M. Gehlhar (eds.), New Directions in Global Food Markets. Electronic Report from the Economic Research Service, USDA, 2005.

[29] P. Walkenhorst, "The geography of foreign direct investment in Poland's food industry," Journal of Agricultural Economics, vol. 52, pp. 71-86, 2001.

[30] C. Hawkes, "The role of foreign direct investment in the nutrition transition," Public Health Nutrition, vol. 8, pp. 357-365.

[31] T. Reardon, C. P. Timmer, C. B. Barrett, and J. A. Berdegue, "The rise of supermarkets in Africa, Asia and Latin America," American Journal of Agricultural Economics, vol. 85, pp. 1140-1146, 2003. 
[32] C. Banwell, J. Dixon, S.-A. Seubsman, S. Pangsap, M. Kelly, and A. Sleigh, "Evolving food retail environments in Thailand and implications for the health and nutrition transition," Public Health Nutrition, vol. 16, pp. 608-615, 2013.

[33] C. Hawkes, "Dietary implications of supermarket development: a global perspective," Development Policy Reviews, vol. 26, pp. 657-692, 2008.

[34] T. F. Randolph, E. Schelling, D. Grace, C. F. Nicholson, J. L. Leroy, D. C. Cole, et al, "Invited Review: Role of livestock in human nutrition and health for poverty reduction in developing countries," Journal of Animal Science, vol. 85, pp. 2788-2800, 2007.

[35] N. J. Temple, and N. P. Steyn. The cost of a healthy diet: A South African perspective. Nutrition, vol. 27, pp. 505-508, 2011.

[36] B. Minten, and T. Reardon, "Food prices, quality, and quality's pricing in supermarkets versus traditional markets in developing countries," Review of Agricultural Economics, vol. 30, pp. 480-490, 2008.

[37] B. Isaacs, J. Dixon, and C. Banwell, "Fresh market to supermarket: nutrition transition insights from Chiang Mai, Thailand," Public Health Nutrition, vol. 13, pp. 893 - 897, 2010.

[38] R. Natawidjaja, T. Reardon, S. Shetty, T. I. Noor, T. Perdana, E. Rasmikayati, et al, "Horticultural producers and supermarket development in Indonesia," UNPAD.MSU Report No, 38543, World Bank/Indonesia, 2007.

[39] P. Moustier, T. A. Dao, A. B. Hoang, B. T. Vu, M. Figuie, and T. G. T. Phan, "Supermarkets and the poor in Vietnam," Malica (Markets and Ag Linkages for Cities in Asia) and M4P (Making Markets Work Better for the Poor), Hanoi, 2006.

[40] A. Devaux, D. Horton, C. Velasco, G. Thiele, G. López, T. Bernet, et al, "Collective action for market chain innovation in the Andes, Food Policy, vol. 34, pp. 31-38, 2009.

[41] M. Gehlhar, and A. Regmi, "Factors shaping global food market," in, A. Regmi, and M. Gehlhar (eds.), New Directions in Global Food Markets. Electronic Report from the Economic Research Service, USDA. http://www.ers.usda.gov/media/872087/aib794c_002.pdf, 2005.

[42] World Bank, "World Data Bank," Malaysia. http://databank.worldbank.org/data/views/reports/tableview. aspx, 2013.

[43] ILO, "Malaysia: Employment by sex and age," http://www.ilo.org/ilostat/faces/home, 2011.

[44] B. M. Popkin, "The nutrition transition: An overview of world patterns of change," Nutrition Reviews, vol. 62, pp. S140-S143, 2004.

[45] A. Nazmi, and C. Monteiro, "The nutrition transition: the same, but different," Public Health Nutrition, vol. 16, pp. $571-572,2013$

[46] N. Gupta, K. Goel, P. Shah, and A. Misra, "Childhood obesity in developing countries: Epidemiology, determinants and prevention,” Endocrine Reviews, vol. 33, pp. 48-70, 2012.

[47] S. Friel, and W. Lichacz, "Unequal food systems, unhealthy diets," in G. Lawrence, K., Lyons, and T. Wallington (eds.),
Food Security, Nutrition and Sustainability, pp. 115-129, London: Earthscan, 2011.

[48] E. S. Tee, Y. Zaitun, M. Appukutty, I. Balaratnam, A. K. Norimah, and H. Zawiah, "Tip Gaya Hidup Sihat," http://www.nutriweb.org.my/nmm2012/NMM2012\%20Mini \%20Booklet\%20-\%20BM\%20Copy.pdf, 2012.

[49] E. S. Tee, "National nutrition policy and national plan of action for nutrition," National Convention on Food Security in Malaysia, 15 - 16 October, Putrajaya, Malaysia, 2012.

[50] N. Kawarazuka, and C. Béné, "Linking small-scale fisheries and aquaculture to household nutritional security: an overview," Food Security, vol. 2, pp. 343-357, 2010.

[51] M. M. Dey, Y. T. Garcia, P. Kumar, S. Piumsombun, M. S. Haque, L. Li, A. Radam, A. Senaratne, et al, "Demand for fish in Asia: a cross-country analysis," The Australian Journal of Agricultural and Resource Economics, vol. 52, pp. 321-338, 2008.

[52] S. Foale, D. Adhuri, P. Aliño, E. H. Allison, N. Andrew, P. Cohen, et al, "Food security and the Coral Triangle Initiative," Marine Policy, vol. 38, pp. 174-183, 2013.

[53] C. A. McAlpine, A. Etter, P. M. Fearnside, L. Seabrook, and W. F. Laurance, "Increasing world consumption of beef as a driver of regional and global change: A call for policy action based on evidence from Queensland (Australia), Colombia and Brazil," Global Environmental Change, vol. 19, pp. 21-33, 2009.

[54] R. York, and M. H. Gossard, "Cross-national meat and fish consumption: exploring the effects of modernization and ecological context," Ecological Economics, vol. 48, pp. 293-302, 2004.

[55] E. Stehfest, L. Bouwman, D. P. van Vuuren, M. G. J. den Elzen, B. Eickhout, and P. Kabat, "Climate benefits of changing diet. Climatic Change, vol. 95, pp. 83-102, 2009.

[56] G. Lawrence, K. Lyons, and T. Wallington, "Introduction: Food security, nutrition and sustainability in a globalized world," In G. Lawrence, K. Lyons, and T. Wallington, T. (eds.), Food Security, Nutrition and Sustainability, pp. 1-23, London: Earthscan, 2011.

[57] R. H. Lustig, L. A. Schmidt, and C. D. Brindis, "The toxic truth about sugar," Nature, vol. 482, pp. 27-29, 2012.

[58] J. Schmidhuber, "The growing global obesity problem: Some policy options to address it," Electronic Journal of Agricultural and Development Economics, vol. 1, pp. 272-290, 2004.

[59] R. T. Jensen, and N. H. Miller, "Do consumer price subsidies really improve nutrition?" Review of Economics and Statistics, vol. 93, pp. 1205-1223, 2011.

[60] X. Guo, B. M. Popkin, T. A. Mroz, and F. Zhai, "Food price policy can favourably alter macronutrient intake in China," Journal of Nutrition, vol. 129, pp. 994-1001, 1999.

[61] C. Hawkes, "Nutrition labels and health claims: The global regulatory environment," Geneva: WHO, 2004.

[62] J. D. Seymour, A. L. Yaroch, M. Serdula, H. M. Blanck, and L. K. Khan, "Impact of nutrition environment and interventions on point-of-purchase behaviour in adults: a review. Preventive Medicine, vol. 39, pp. S108-S136, 2004. 
[63] D. Coitinho, C. A. Monteiro, and B. M. Popkin, "What Brazil is doing to promote healthy diets and active lifestyles," Public Health Nutrition, vol. 5, pp. 263-267, 2002.

[64] P. Pekka, P. Pirjo, and U. Ulla, "Influencing public nutrition for non-communicable disease prevention: from community intervention to national programme - experiences from Finland," Public Health Nutrition, vol. 5, pp. 245 - 251, 2002.

[65] NCCFN, "Malaysian Dietary Guidelines," National Coordinating Committee on Food and Nutrition, Ministry of Health Malaysia, pp. $1-128$, Putrajaya: Ministry of Health, 2010.

[66] NCCFN, "Malaysian Dietary Guidelines for Children and Adolescents," National Coordinating Committee on Food and Nutrition, Ministry of Health Malaysia, pp. $1-285$, Putrajaya: Ministry of Health, 2013.

[67] E. S. Tee, Y. Zaitun, M. Appukutty, Y. H. Tan, S. Ridzoni, A. K. Norimah, A. K., et al, "Eat Right, Enjoy Life. A Guide and Recipe Book of the Nutrition Month Malaysia 2008," http://www.nutriweb.org.my/downloads/Eat\%20right\%20en joy\%20life.pdf, 2008.
[68] E. S. Tee, Y. Zaitun, M. Appukutty, Y. H. Tan, S. Ridzoni, A. K. Norimah, et al, "Raising Healthy Eaters. A Guide and Recipe Book of the Nutrition Month Malaysia 2009," http://www.nutriweb.org.my/nmm2011/Raising\%20health\% 20eaters\%20final\%20no\%20year.pdf, 2009a.

[69] E. S. Tee, Y. Zaitun, M. Appukutty, Y. H. Tan, S. Ridzoni, A. K. Norimah, et al, "Easy Nutrition Planner. A Guide and Recipe Book of the Nutrition Month Malaysia 2009," http://www.nutriweb.org.my/downloads/NMM\%202009\%2 0Easy\%20Nutrition\%20Planner\%20(MOH)\%20Low\%20Re s.pdf, $2009 \mathrm{~b}$.

[70] E. S. Tee, Y. Zaitun, M. Appukutty, I. Balaratnam, A. K. Norimah, and H. Zawiah, "Smart Nutrition for Your Active Growing Kids. A Guide and Recipe Book of the Nutrition Month Malaysia 2010," http://www.nutriweb.org.my/downloads/NMM\%202010\%2 0Smart\%20Nutrition\%20(MOH)\%20Low\%20Res.pdf, 2010 . 